\title{
The Differences of Elementary School Students' Interest on Traditional Games and Online Games
}

\author{
Gustiana Mega Anggita ${ }^{1}$, Hari Amirullah Rachman ${ }^{2}$, Chang Yun-Chen ${ }^{3}$, Sugiarto ${ }^{4}$, Moham- \\ mad Arif Ali ${ }^{5}$, Cholid Chaerudin ${ }^{6}$, Adiska Rani Ditya Candra ${ }^{7}$, Fuadah Nor Wiqoyatul Milla ${ }^{8}$ \\ \{mega.anggita@mail.unnes.ac.id ${ }^{1}$, hari.rachman68@gmail.com ${ }^{2}$, zoot79525@gmail.com ${ }^{3}$ \} \\ Universitas Negeri Semarang, Semarang, Indonesia ${ }^{1}$, \\ Yogyakarta State University, Sleman, Indonesia ${ }^{2}$, \\ National Tsing Hua University, Hsinchu City, Taiwan ${ }^{3}$
}

\begin{abstract}
Children's interest is one indicator that can illustrate the popularity of the game. Nowdays, online games are developing rapidly and traditional games are getting forgotten. This study aims to find differences in elementary school students' interest in traditional games and online games. The method used is quantitative descriptive with a sample of 80 elementary school students in Semarang City. Data collection techniques using a questionnaire. Data were analyzed using t-test with SPSS 21 series. There are significant differences between elementary school students' interest towards traditional games and online games with significant value $0.000<0.05$. Elementary school students' interest towards traditional games is higher than online games with an average score of traditional games as much as 21.025 and an average score of online games as much as 14.663. Elementary school students' interest towards traditional games is higher than online games.
\end{abstract}

Keywords: interest, children, traditional games, online games

\section{Introduction}

The Era of Digitalization is marked by the increasing use of electronic devices in human life. Nowadays electronic devices, especially gadgets became the major component in human life. This is evident from the increasing number of Internet usage each year. Overall, the number of Internet users worldwide is projected to reach 3 billion people by 2015 . Three years later, in 2018, an estimated 3.6 billion people on earth will access the internet at least once every month and Indonesia is the country with the 6th largest number of internet users after China, the United States, India, Brazil, and Japan [1, 2]. The development of devices now is evenly distributed in all ages including children aged 5 years and even under 5 years [3]. The widespread use of devices in children makes the development of online games more rapidly.

Play is an activity that can provide fun and relaxation for those who do it. Play is part of the children's world and are not separated from each other [4]. Through play children can explore the knowledge and skills that exist within him. Therefore play an important activity to be performed by children $[5,6]$. The development of the type of game today is very diverse ranging from traditional games that involve more physical abilities to online games that are currently popular among children. 
Traditional games are one form of physical activity that has community cultural values [7]. Traditional games and sports reflect different cultural expressions and create bridges between cultures for mutual understanding. Preservation and promotion of traditional games and sports provide an important and essential contribution to the world cultural heritage [8]. Traditional games are not merely games, in traditional games there are cultural elements that are strongly attached and must continue to be preserved [9]. The traditional game is a game that has elements of a culture that grow and develop in society in accordance with the rules and norms and customs inherited hereditary maintained using either a tool or without tools in play $[10,11]$. Traditional games are the result of great cultural value for children in order to fantasize, recreate, be creative, exercise as well as a means of training for community life, skills, politeness and dexterity [12]. Traditional games tend to encourage children to do physical activity that is beneficial to the growth and development of the body, in addition, encourage traditional games encourage children to learn to work together and respect each other. Traditional games directly affect the psychomotor, cognitive and emotional development of children. Traditional games can influence the enjoyment of players and positively affect the overall development of children [13]. Traditional games are one of the physical activities used in teaching and learning activities, especially in physical education learning. Playing traditional games in learning encourages social interaction in learning, a competitive spirit, and friendship that occurs during game-play [14].

Online games are games that are connected through an internet-based network that is played using a computer, gadget, laptop or other device [15]. Online games are a recreational tool that is widely used by many people. For the majority of people playing online games (video games) can be a stress reliever, relaxation, social interaction, challenges and competitions, pleasure [16]. Online games are one product of advances in science and technology. Online games have evolved as gadget have expanded. Online games can be found and played on various devices such as smartphones, laptops, tablets and computers. With all the conveniences that exist in online games make people interested in trying to play it. Nowadays online games have very much demand ranging from children to adults, online games using computers provide more stimulation to play compared to other online games because of the rapid and instant gratification they provide [6]. The positive impact of online games is that they are able to develop people's visual-spatial abilities through the process of practicing processing spatial information from the monitor screen [17].

Traditional games and online games each have benefits in human life. Through physical education traditional games are still being introduced and preserved [18]. While the progress of the internet network and the many uses of gadgets make online games increasingly popular nowadays. When talking about physical activity, traditional games are important activities that should performed by children but online game also has benefical for children's knowledge ability like processing spatial information. Previous studies have not explored data related to elementary school students' interest in traditional games and online games. This study aims to determine differences in elementary school students' interest in traditional games and online games.

\section{Methods}

The survey method was used in this study. A total of 80 elementary school students in Semarang were respondents in this study. The sampling technique used purposive sampling 
with inclusion criteria include: 1) Have status of elementary school students; 2) 10-13 years old; 3) Willing to fill in the availability form to be a respondent and 4) Fill in the questionnaire interest in traditional games and online games. Procedures in this study include: 1) Subjects get an explanation of the background of the research, 2) Subjects get an explanation of the stages they have to do, 3) Subjects fill out an approval letter to be a research respondent, 4) Subjects get an explanation of how to fill in traditional game questionnaires and online games, 5) Subjects fill out questionnaire interest in traditional games and online games, 6) Data on traditional games and online games are processed to get the value of interest in traditional games and online games. Data collection techniques in this study is the use of questionnaires. the questionnaire used for data collection in this study were two questionnaires consisting of: 1) traditional game interest questionnaire and 2) online game interest questionnaire. Measurement questionnaire in this study uses a Likert scale. Data analysis using t-test using SPSS series 21 . The significance value of $0.05 \leq p \leq 0.05$ will be considered for data interpretation with the prerequisite test before analysis.

\section{$3 \quad$ Results and discussions}

Playing in the learning process can provide a variety of movement experiences for children, where the experience of movement is very instrumental in the process of growth and development of children. Motion development for elementary school children is defined as the development and refinement of various basic motion skills and motion skills related to sports [11]. Through play, children can explore the abilities that exist within themselves and learn new skills. Based on the data obtained as many as $17.21 \%$ of respondents were 10 years old, $43.54 \%$ were 11 years old, $18.22 \%$ were 12 years old and $2.3 \%$ were 13 years old consisting of: 1) 9 male students and 7 female students aged 10 years old; 2) 23 male students and 21 female students aged 11 years old; 3) 9 male students and 9 female students aged 12 years old; 4) no male students and 2 female students aged 10 years old.

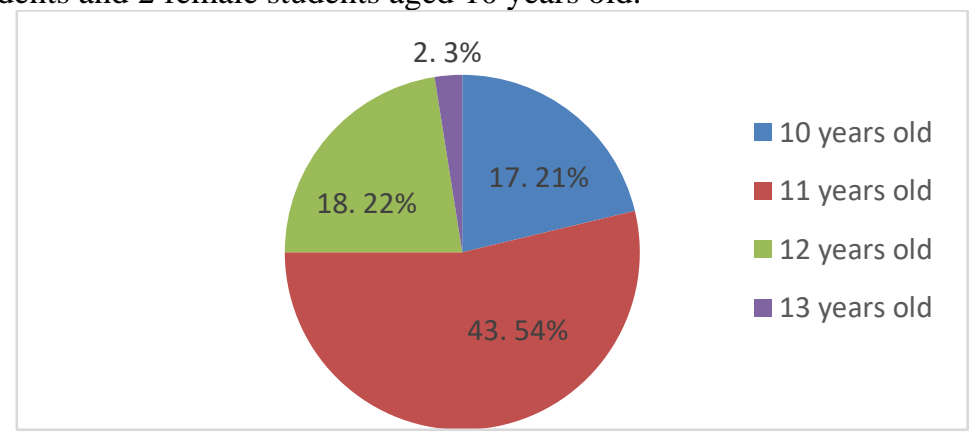

Fig. 1. Respondent's age data 


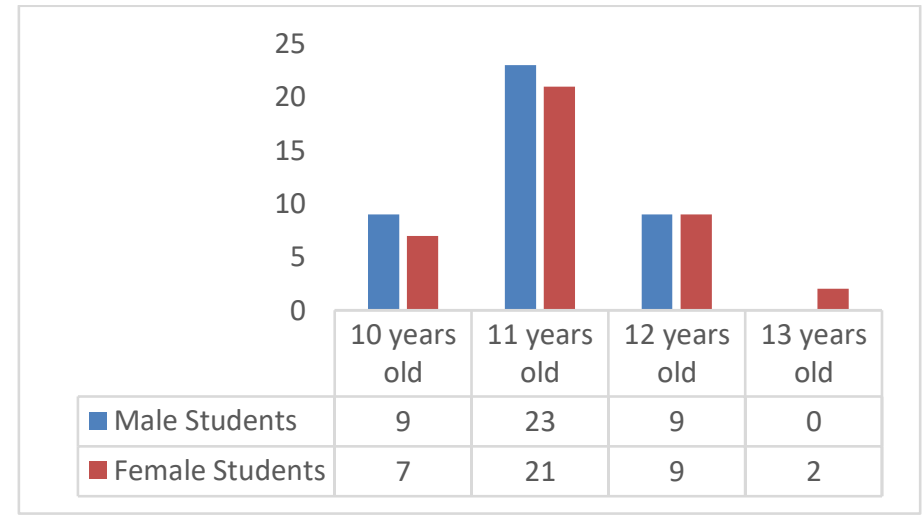

Fig. 2. Responden participation data

The development of traditional games and online games is influenced by one's interest in these types of games. The rise of gadgets uses makes online games increasingly popular among the public, including children. At present the gadget is inseparable from human life. Gadgets have become a necessity of daily life, starting from the activities of Education, Health, buying daily necessities and transportation, and have used gadgets. Technological progress is like two sides of a coin, where on the one hand technological advancements provide many positive benefits for humans to make it easier for humans to meet their needs. However, on the other hand, technological progress has a complex negative effect that exceeds the benefits of the technology itself, especially related to human life patterns in the socio-cultural dimension [18]. Interest is a form of gesture that shows enthusiasm in performing certain activities. Interest is one of the initial steps for someone to participate in certain activities. If the level of interest is high, participation in these activities will also increase. When participation increases it will have an impact on the development of traditional games and online games.

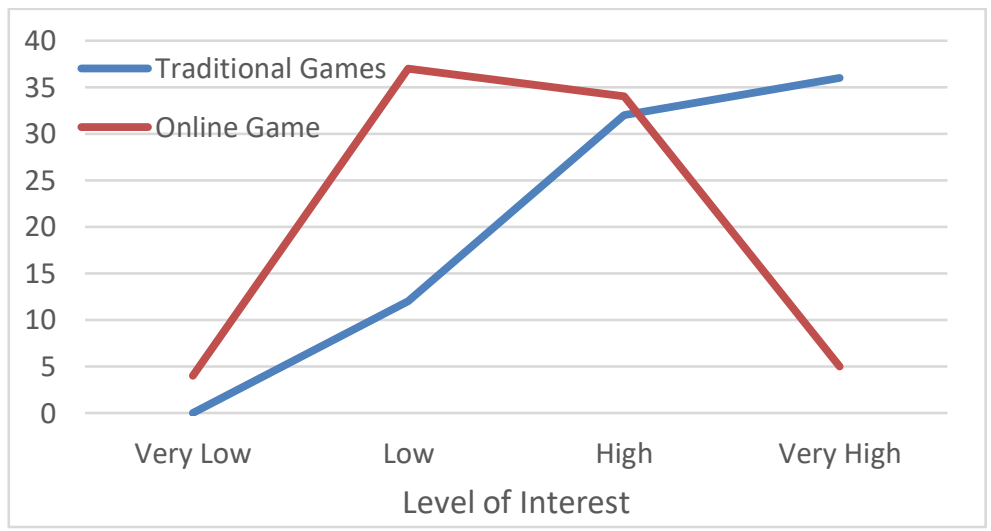

Fig. 3. elementary school students' interest towards traditional games and online games 
Based on the data above it is known that elementary school students' interest in traditional games is $45 \%$ of students having very high interest, $40 \%$ of students having high interest, $15 \%$ of students having low interest and none of students having very low interest. In addition, the elementary school students' interest towards the online game as much as $6,25 \%$ of students have a very high interest, $42.5 \%$ of students have a high interest, $46.25 \%$ of students have a low interest and $5 \%$ of the students have a very low interest.

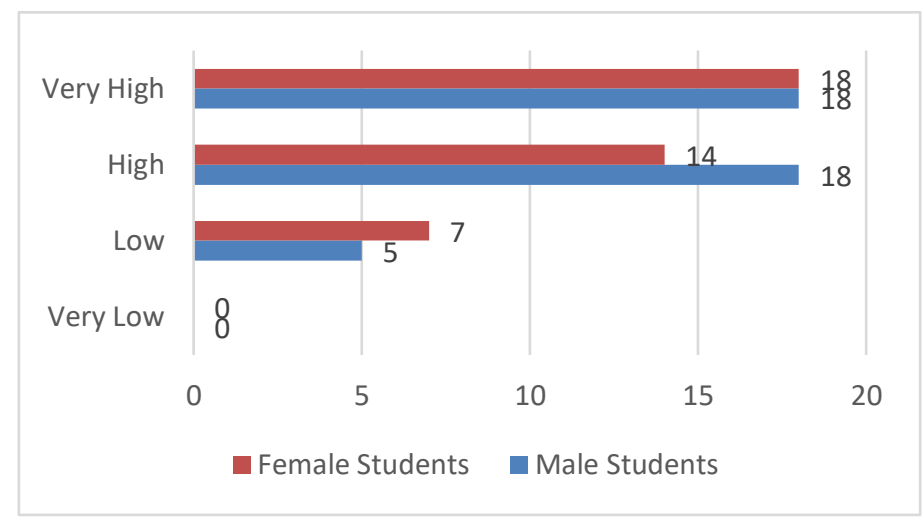

Fig. 4. Elementary School Students' interest Toward Traditional Games

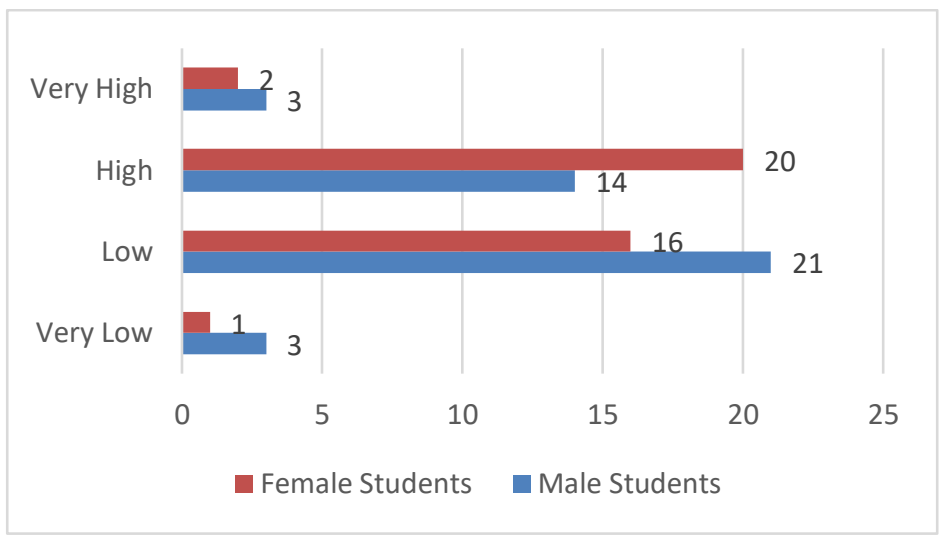

Fig. 5. Elementary School Students' interest Toward Online Games 
Table 1. Difference of elementary school students' interest between traditional games and online games

\begin{tabular}{cccc}
\hline Type of Game & $\begin{array}{c}\text { T-test } \\
\text { value }\end{array}$ & $\begin{array}{c}\text { Sig. } \\
\text { (2-tailed) }\end{array}$ & $\begin{array}{c}\text { Mean } \\
\text { Difference }\end{array}$ \\
\hline Traditional Games & 34.59 & 0.00 & 21.02 \\
Interest & 8 & 0 & 5 \\
Online Game Interest & 29.17 & 0.00 & 14.66 \\
& 9 & 0 & 3 \\
\hline
\end{tabular}

Based on that data, there are significant differences between elementary school students' interest towards traditional games and online games with significant value $0.000<0.05$. Elementary school students' interest towards traditional games is higher than online games with an average score of traditional games as much as 21.025 and an average score of online games as much as 14.663. Elementary school students' interest towards the game is still higher than that of traditional online games. The development of digital devices made people begin to leave the traditional way of life. Although modernization changes the patterns of human life but in some aspects they still use traditional patterns. The inclusion of sophistication of technology brings traditional people of Indonesia to be more practical. Now the public considers traditional games or sports to be replaced by online games and fitness centers [19].

Basically traditional games and online games have a positive values on children. Traditional games involving physical activity provide benefits for the development of thinking, problem solving, basic motion development and social skills. Traditional games are facilities for children to play. Besides being beneficial for health, fitness and child development, there are also positive values contained in traditional games such as honesty, cooperation, sportsmanship, helping each others, responsibility, discipline and many more where these things can build the character of children $[9,20]$. Beside the positive impact found on traditional games, the high interest on traditional games compare online game is due to inherent values of national culture. Online games are types of games that involve digital devices and internet networks. Online gaming means you can play in real time with people across the world through a computer, games console, tablet or smartphone connected to the internet. Games can offer children a world of adventure to immerse themselves in, but it's important to understand how children can stay safe and what games are appropriate for their age. There are also positive impact for children such as: 1) enhance memory, brain's speed, and concentration; 2) Improved multi-tasking skills; 3) Promotes teamwork and builds confidence; 4) physical and social benefit $[21,22]$.

Although both of the games has positive values on children, online game also has negative impact on children. As we know that online game not involving physical activity to performed it, children can play the game everywhere and everytime they want. It can makes children less activity and become obese. Preschool children with high intensity gadget usage have a 2.1 times greater chance of being obese compared to preschool children with low gadget usage intensity [23].Uncontrolled gadget uses also affecting children's social and emotional, children become has negative characters such as shy, lacking confidet, lonely, stubborn and do not have good communication skills with other people [24, 25]. Therefore, every parent needs to controle and give more attention to their children if they play online game. If children play online games without under parents supervision, they become addicted to online games. To prevent children addicted to online games, parent can take some strategy such as: 1) select according to the child's age, 2) Selective choosing game applications in gadgets, 3) Accompa- 
ny the child in play, 4) Limit your child's time playing gadget, and 5) Inviting children to do positive activities [26].

Based on our findings,elementary school student's interest on traditional games is still higher than online games but to face of digitalization era, precise strategies are needed in preserving traditional games and appropriate strategies are needed in supervising children from the negative effects of excessive use of gadgets and online games.

\section{Conclusion}

Elementary school students' interest towards traditional games is higher than online games. Both traditional games and online games have positive benefits for children's growth and development. However, playing online games for children requires more supervision from parents because there is a negative impact if children play online games without parental supervision.

The high interest of children on traditional games makes traditional games will still exist even though online games are growing rapidly. Positive values that support children's character are one of the reasons traditional games have become the choice of physical activity for children. Although online games have some negative effects, the positive benefits can be obtained by children with restrictions of gadgets use and parental supervision on duration and intensity of playing online games.

\section{Acknowledgements}

The Author would like to thank the support of Sport Science Faculty Universitas Negeri Semarang for giving grants to this research. The authors also thanks to our responden for willingness to become a research sample and participate in filling out a research questionnaire.

\section{References}

[1] Kominfo. Pengguna Intenet Indonesia Nomor Enam Dunia [Internet]. Kompas.com. 2014. Available from: https://kominfo.go.id/content/detail/4286/pengguna-internet-indonesia-nomor-enamdunia/0/sorotan_media.

[2] Supratman LP. Penggunaan Media Sosial oleh Digital Native. J Ilmu Komun. 2018;15(1):47-60.

[3] Fajariyah SN, Suryawan A. Dampak Penggunaan Gawai Terhadap Perkembangan Anak. Sari Pediatr. 2018;20(2):101-105.

[4] Maricar F, Tawari RS. NILAI DAN EKSISTENSI PERMAINAN TRADISIONAL DI TERNATE. J ETNOHISTORI. 2018;V(2):162-184.

[5] Gelisli Y, Yazici E. A Study into Traditional Child Games Played In Konya Region In Terms Of Development Fields of Children. Procedia - Soc Behav Sci [Internet]. 2015;197(February):185965. Available from: http://dx.doi.org/10.1016/j.sbspro.2015.07.247.

[6] Karaca S, Karakoc A, Can O, Nevin G, Gul O, Barlas U. Investigation of the Online Game Addiction Level, Sociodemographic Characteristics and Social Anxiety as Risk Factors for Online Game Addiction in Middle School Students. Community Ment Health J [Internet]. 2020;56(5):830-838. Available from: https://doi.org/10.1007/s10597-019-00544-z.

[7] Akbari H, Abdoli B, Shafizadeh M, Khalaji H, Hajihosseini S, Ziaee V. The Effect of Traditional Games in Fundamental Motor Skill Development in 7-9 Year-Old Boys. Iran J Pediatr. 2009;19(2):123-129. 
[8] Boro J, Daimary R, Narzaree B. Impact of Globalisation to Traditional Games and Recreation of the Bodos. IOSR J Humanit Soc Sci. 2015;20(3):87-91.

[9] Hikmah Prisia Yudiwinata HP, Handoyo P. Permainan Tradisional dalam Budaya dan Perkembangan Anak. Paradigma. 2014;2:1-5.

[10] Kadek NI, Rahmadani A. Pertiwi Kabupaten Trenggalek sela- Permainan tradisional Jawa. J Pendidik Usia Dini. 2014;8(2):305-314.

[11] Mega Anggita G (Universitas NS, Amirullah Rachman H (Universitas NY. PENGARUH AKTIVITAS BERMAIN DAN PERSEPTUAL MOTORIK TERHADAP KETERAMPILAN MOTORIK SISWA SEKOLAH DASAR KELAS BAWAH. J Keolahragaan. 2014;2(1):130-44.

[12] Andriani T. Permainan Tradisional Dalam Membentuk Karakter Anak Usia Dini. Sos Budaya. 2012;9(1):121-136.

[13] Kovacevic T, Opic S. Contribution of Traditional Games to the Quality of Students' Relations and Frequency of Students' Socialization in Primary Education. Croat J Educ Cas Za Odgoj I Obraz. 2014;16(1):95-112.

[14] Trajkovik V, Malinovski T, Vasileva-stojanovska T. Traditional games in elementary school: Relationships of student' $s$ personality traits, motivation and experience with learning outcomes. PLoS One. 2018;1-15.

[15] Haeril. Indeks Massa Tubuh Anak yang Aktif Bermain Game Online dan Anak yang Tidak Aktif Bermain Game Online. Jendela Olahraga. 2019;4(2):44-49.

[16] Dumrique DO, Castillo JG. Online Gaming: Impact on the Academic Performance and Social Behavior of the Students in Polytechnic University of the Philippines Laboratory High School. In: 4th International Research Conference on Higher Education. 2018. p. 1205-1210.

[17] Putu N, Pramesti R, Odelia A, Trisna E, Adinda H, Valeska S, et al. Sosialisasi dampak game online terhadap anak-anak. Masy Budaya dan Inov. 2020;1(2):69-73.

[18] Anggita GM, Baitul S, Arif M. Eksistensi Permainan Tradisional Sebagai Warisan Budaya Bangsa. J Sport Sci Educ. 2018;3(2):56-59.

[19] Ngafifi M. Advances in Technology and Patterns of Human Life in Socio-Cultural Perspective. Kemajuan Teknol dan Pola Hidup Mns [Internet]. 2014;2(1):33-47. Available from: http://journal.uny.ac.id/index.php/jppfa/article/viewFile/2616/2171.

[20] Gede D, Arsana P. Tranformasi Budaya Dalam Permainan Tradisional Menuju Game Online. Media Komun FPIPS. 2016;15(2):41-45.

[21] Parisod H, Aromaa M, Kauhanen L, Kimppa K, Laaksonen C, Leppänen V, et al. The advantages and limitations of digital games in children' $s$ health promotion. Finnish J eHealth eWelfare. 2014;6(4):164-173.

[22] Robetson A. The Gaming Advice Hub, Get expert tips on gaming to support children [Internet]. Internet Matters. 2020. Available from: https://www.internetmatters.org/resources/online-gamingadvice/.

[23] Tanjung FS, Huriyati E, Ismail D. Intensity of Gadget Use Among Overweight Preschool Children in Yogyakarta. BKM J Community Med Public Heal. 2017;33(12):603-608.

[24] Zubaidah Z. Hubungan Durasi Penggunaan Gadget Terhadap Perkembangan Sosial Anak Prasekolah di TK PGRI 33 Sumurboto, Banyumanik. 2017.

[25] Wahyuni AS, Siahaan FB, Arfa M, Alona I, Nerdy N. The Relationship between the Duration of Playing Gadget and Mental Emotional State of Elementary School Students. Maced J Med Sci. 2019;7(1):148-151.

[26] Novitasari N. Strategi Pendampingan Orang Tua Terhadap Intensitas Penggunaan Gadget Pada Anak. Indones J Early Child Islam Educ. 2019;3(2):167-188. 